\title{
Synthesis of Sugar Oxazolines by Intramolecular Ritter-Like Reaction of D-Fructose Precursors
}

\author{
José L. Jiménez Blanco, ${ }^{a}$ Enrique M. Rubio, ${ }^{\mathrm{b}}$ Carmen Ortiz Mellet, ${ }^{* a}$ José M. García Fernández*b \\ a Departamento de Química Orgánica, Facultad de Química, Universidad de Sevilla, Aptdo. 553, 41071 Sevilla, Spain \\ Fax +34(954)624960; E-mail: mellet@us.es \\ b Instituto de Investigaciones Químicas, CSIC, Américo Vespucio 49, Isla de la Cartuja, 41092 Sevilla, Spain \\ Fax +34(954)460565; E-mail: jogarcia@iiq.csic.es \\ Received 20 May 2004
}

\begin{abstract}
Treatment of D-fructopyranose and D-fructofuranose $1,2-O$-acetonide derivatives with triflic acid in the presence of a variety of nitriles results in the formation of fused or spiro 2-oxazolines. The reaction implies (i) activation of the anomeric centre with simultaneous isopropylidene cleavage, (ii) nucleophilic addition of the nitrile to the corresponding oxocarbenium cation intermediate and (iii) subsequent trapping of the resulting nitrilium ion species by the remaining hydroxyl group in an intramolecular Ritter-like reaction.
\end{abstract}

Key words: carbohydrates, nitriles, 2-oxazolines, spiro compounds, Ritter reaction

2-Oxazolines constitute a wide family of five-membered heterocycles with important applications in the fields of organic synthesis, ${ }^{1}$ catalysis, ${ }^{2,3}$ and pharmacology. ${ }^{4} 2$ Amino-2-deoxysugar 2-oxazoline derivatives have been broadly used as glycosyl donors in the synthesis of natural oligosaccharides ${ }^{5}$ and have also been proposed as glycosidase substrates ${ }^{6}$ and inhibitors. ${ }^{7}$ Recently, interest in the synthesis of the isomeric glycosylamine 2-oxazoline derivatives (glycosyl isooxazolines) has grown because these compounds can serve as intermediates in the stereoselective construction of the glycosyl amide bond, a key structural feature of $\mathrm{N}$-glycoproteins. ${ }^{8}$ However, further applications have been limited so far due to the lack of suitable preparative methods and the relative instability of the anomeric 2-oxazoline ring.

The Ritter reaction, ${ }^{9}$ i.e., the generation of a relatively stable carbocation and its in situ trapping by nitriles, to give transient nitrilium species that can undergo further inter or intramolecular nucleophilic attack by a suitably located group, is an attractive strategy for the preparation of a variety of amide products and azaheterocycles that has already found utility in carbohydrate chemistry. ${ }^{10}$ Transient glycosyl isooxazoline intermediates have been already invoked in some Ritter-like transformations. ${ }^{11}$ Yet, only in a few cases they have been isolated and fully characterized. ${ }^{12}$ In previous work, we have shown that D-fructose isopropylidene derivatives can be readily activated with triflic acid to give a transient $\beta$-hydroxy oxocarbenium cation. ${ }^{13}$ In the absence of any other nucleophile, spirodi-

SYNLETT 2004, No. 12, pp 2230-2232

Advanced online publication: 04.08.2004

DOI: 10.1055/s-2004-830891; Art ID: D12704ST

(c) Georg Thieme Verlag Stuttgart · New York saccharides (di-D-fructose dianhydrides) are formed. We now report the extension of this strategy to the stereoselective preparation of fused and spiro glycosyl isoxazolines by a Ritter-like reaction involving (i) nitrile addition to the fructosyl cation and (ii) subsequent intramolecular trapping of the initially formed nitrilium ion by the vicinal free hydroxyl group (Scheme 1).

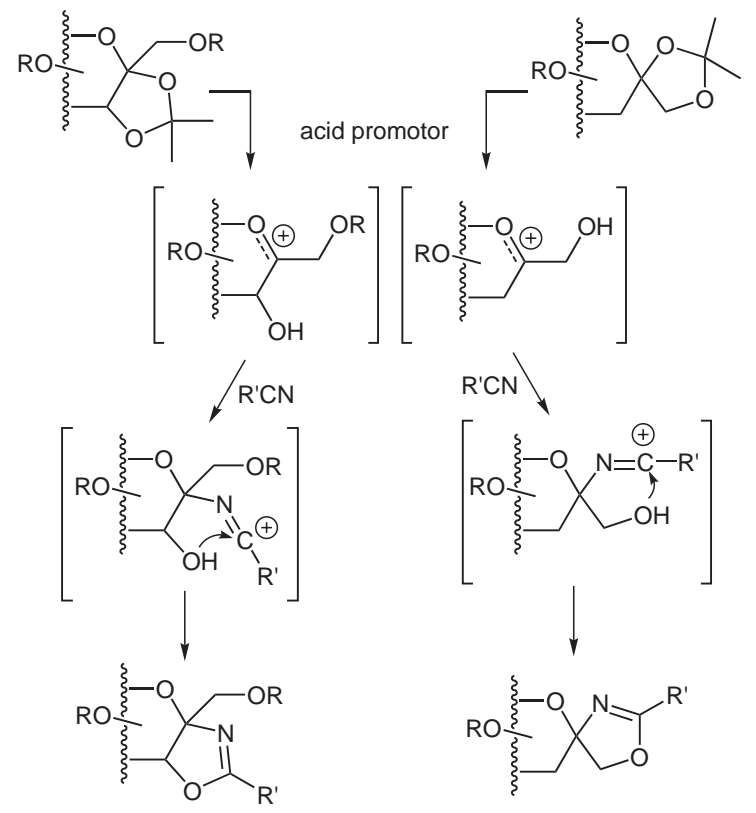

Scheme 1 Synthesis of fused and spiro glycosyl isooxazolines from D-fructose isopropylidene derivatives by Ritter-like reaction

A wide variety of nitriles was found to participate in the addition-cyclization reaction. In the case of 1 - $O$-benzyl2,3:4,5-di- $O$-isopropylidene- $\beta$-D-fructopyranose $\quad(\mathbf{1}),{ }^{14}$ the corresponding fused isooxazoline with $\beta$-anomeric configuration $(\mathbf{6 a}-\mathbf{d})$ was the only reaction product (Figure 1 and Table 1, entries 1-4). The stereochemical outcome is governed in this case by the orientation of $\mathrm{OH}$ 3 , formation of a trans-fused bicyclic system being prevented due to steric strain. Contrary to that reported for previous preparations of aldose-derived glycosyl isooxazolines, compounds $\mathbf{6 a - d}$ were found to be rather stable. In fact, it is known that the stability of the oxazolinium cation increases with the number of electron-donating carbon substituents in the ring. ${ }^{15}$ Moreover, oxazolinium 
triflates are still more stable, since the triflate counterion is a very weak nucleophile, which is unable to attack the oxazolinium ring. ${ }^{16}$

Activation of 1,2:4,5-di- $O$-isopropylidene- $\beta$-D-fructopyranose precursors $(\mathbf{2} \text { and } \mathbf{3})^{14}$ with triflic acid in the presence of a nitrile afforded spiro isooxazolines (7a-d and $\mathbf{8}$, respectively). ${ }^{17}$ Only the $\beta$-configured compounds, having the pyranose ring in the ${ }^{1} C_{4}$ conformation, were detected, irrespective of the participating (benzoyl) or nonparticipating character (benzyl) of the hydroxyl protecting group at O-3 (Table 1, entries 5-9). It is noteworthy that this situation implies the axial orientation of the N-substituent at the anomeric position, a generally unfavorable arrangement for $\mathrm{N}$-glycosidic derivatives due to the reverse anomeric effect. ${ }^{18}$ In fact, the preference for the axial orientation has previously been observed in the case of glycosylacetonitrilium ions, which have been trapped as the corresponding imides by reaction with carboxylic acids. ${ }^{19}$ Our results indicate that this scenario is probably general for glycosylnitrilium salts. Moreover, the decreased positive charge density at the isooxazoline nitrogen atom, as compared with amines, in combination with the preferred equatorial orientation for the carbon substituent, probably prevents anomerization of the final compounds, a typical problem in the case of per-O-protected glycosylamine derivatives. ${ }^{20}$

3,4,6-Tri-O-protected $1,2-O$-isopropylidene- $\beta$-D-fructofuranose derivatives $(\mathbf{4} \text { and } 5)^{21}$ likewise afforded spiro isooxazolines having the $\beta$-anomeric configuration at the fructose moiety upon reaction with acetonitrile under the above reaction conditions $(\mathbf{9}$ and $\mathbf{1 0}$, respectively, Table 1, entries 10 and 11). In the case of the benzoylated precursor, however, the cis-fused bicyclic isooxazoline 11, arising from O-3 to O-1 acyl migration prior to oxazoline ring closure, was the major reaction product (Table 1,
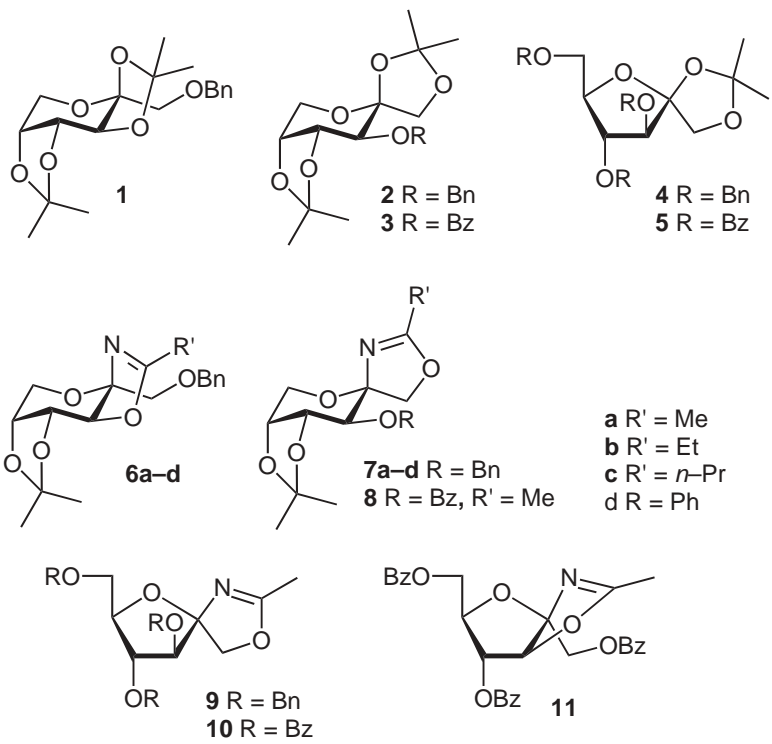

Figure 1 Structures of the fused and spiro glycosyl isooxazolines prepared in this study and of the corresponding D-fructose precursors entry 11), in agreement with the higher stability of the fused isooxazoline skeleton as compared with the spiro glycosyl isooxazoline framework.

In summary, the Ritter-based strategy reported herein is effective for accessing fused as well as spiro glycosyl isooxazolines from readily obtainable D-fructose acetonides. The commercial availability of a large number of nitriles and the simplicity of the method should be attractive not only to exploit the rich chemistry of 2-oxazolines in carbohydrate transformation schemes but also for the preparation of chiral 2-oxazoline libraries, of interest as ligands in asymmetric catalysis. Work in both directions is currently being investigated in our laboratories.

Table 1 Glycosyl Isooxazolines Formed by Reaction of D-Fructose 1,2-O-Acetonides with Nitriles Using Triflic Acid as Promotor ${ }^{\mathrm{a}}$

\begin{tabular}{|c|c|c|c|c|}
\hline Entry & $\begin{array}{l}\text { D-Fructose } \\
\text { precursor }\end{array}$ & Nitrile & $\begin{array}{l}\text { Reaction time } \\
\text { (h) }\end{array}$ & $\begin{array}{l}\text { Products } \\
\text { (yield, \%) }\end{array}$ \\
\hline 1 & 1 & $\mathrm{MeCN}$ & 1 & $\mathbf{6 a}(80)$ \\
\hline 2 & 1 & $\mathrm{EtCN}$ & 1 & $\mathbf{6 b}(71)$ \\
\hline 3 & 1 & $n$-PrCN & 5 & 6c (75) \\
\hline 4 & 1 & $\mathrm{PhCN}$ & 3 & 6d (65) \\
\hline 5 & 2 & $\mathrm{MeCN}$ & 1 & $7 \mathbf{a}(50)$ \\
\hline 6 & 2 & $\mathrm{EtCN}$ & 0.5 & $7 \mathbf{b}(63)$ \\
\hline 7 & 2 & $n-\mathrm{PrCN}$ & 0.5 & 7c (83) \\
\hline 8 & 2 & $\mathrm{PhCN}$ & 0.5 & $7 d(65)$ \\
\hline 9 & 3 & $\mathrm{MeCN}$ & 1 & $8(41)$ \\
\hline 10 & 4 & $\mathrm{MeCN}$ & 0.5 & $9(48)$ \\
\hline 11 & 5 & $\mathrm{MeCN}$ & 3 & $\begin{array}{l}10(15) \\
11(44)\end{array}$ \\
\hline
\end{tabular}

a All reactions were carried out in $\mathrm{CH}_{2} \mathrm{Cl}_{2}$ at $-20{ }^{\circ} \mathrm{C}$ to r.t. using 10 equiv of the nitrile and 1.5 equiv of the acid promotor.

General procedure: To a $0.114 \mathrm{M}$ solution of the corresponding Dfructose precursor $\mathbf{1}-\mathbf{5}$ and the nitrile counterpart (10 equiv) in distilled $\mathrm{CH}_{2} \mathrm{Cl}_{2}$ at $-20{ }^{\circ} \mathrm{C}$, TfOH (1.5 equiv) was added under Ar atmosphere. The reaction mixture was allowed to warm up to r.t. and stirred for the time indicated in Table 1 . Then $\mathrm{Et}_{3} \mathrm{~N}$ was added, the solvents were evaporated under reduced pressure and the products were purified by column chromatography using mixtures of EtOAc-petroleum ether as eluent. All products gave satisfactory MS and microanalysis data in agreement with the proposed structures. The isolated yields are indicated in Table 1.

Selected data ${ }^{22}$ for $\mathbf{6 a}: \mathrm{R}_{\mathrm{f}}=0.22$ (1:2 EtOAc-petroleum ether); $[\alpha]_{\mathrm{D}}$ $-90\left(c 0.8, \mathrm{CH}_{2} \mathrm{Cl}_{2}\right) .{ }^{1} \mathrm{H}$ NMR $\left(500 \mathrm{MHz}, \mathrm{CDCl}_{3}\right): \delta=7.22(\mathrm{~m}, 5 \mathrm{H}$, $\mathrm{Ph}), 4.62\left(\mathrm{~d}, 1 \mathrm{H}, \mathrm{CH}_{2} \mathrm{Ph}\right), 4.60$ (dd, $\left.1 \mathrm{H}, \mathrm{H}-4\right), 4.56(\mathrm{~d}, 1 \mathrm{H}, \mathrm{H}-3)$, 4.55 (d, $\left.1 \mathrm{H}, \mathrm{CH}_{2} \mathrm{Ph}\right), 4.13$ (dd, $\left.1 \mathrm{H}, \mathrm{H}-5\right), 3.73$ (d, $\left.1 \mathrm{H}, \mathrm{H}-1 \mathrm{a}\right), 3.71$ (d, 1 H, H-6a) 3.59 (d, 1 H, H-1b), 3.31 (dd, 1 H, H-6b), 2.04 (s, 3 $\mathrm{H}, \mathrm{NMe}), 1.39,1.30\left(2 \mathrm{~s}\right.$, each $\left.3 \mathrm{H}, \mathrm{CMe} e_{2}\right) \mathrm{ppm} .{ }^{13} \mathrm{C}$ NMR $(125.7$ $\left.\mathrm{MHz}, \mathrm{CDCl}_{3}\right): \delta=168.0(\mathrm{CN}), 138.1,128.3,127.6,127.5(\mathrm{Ph})$, $109.1\left(\mathrm{CMe}_{2}\right), 98.7(\mathrm{C}-2), 73.5\left(\mathrm{CH}_{2} \mathrm{Ph}\right), 73.1(\mathrm{C}-1), 72.8(\mathrm{C}-3)$, 70.4 (C-5), 69.8 (C-4), 60.9 (C-6), 26.0, $24.3\left(2 \mathrm{CMe}_{2}\right), 13.9$ (NMe) ppm. 
Selected data for 7a: $\mathrm{R}_{\mathrm{f}}=0.54$ (2:1 EtOAc-petroleum ether); $[\alpha]_{\mathrm{D}}$ $-61\left(c 0.7, \mathrm{CH}_{2} \mathrm{Cl}_{2}\right)$. The corresponding ${ }^{1} \mathrm{H}$ NMR and ${ }^{13} \mathrm{C}$ NMR data were in agreement with those reported in the literature. ${ }^{17}$

Selected data ${ }^{22}$ for $8: R_{\mathrm{f}}=0.34$ (1:1 EtOAc-petroleum ether); $[\alpha]_{\mathrm{D}}$ -132 (c $0.9, \mathrm{CH}_{2} \mathrm{Cl}_{2}$ ). ${ }^{1} \mathrm{H}$ NMR (500 MHz, $\mathrm{CDCl}_{3}$ ): $\delta=8.02-7.41$ $(\mathrm{m}, 5 \mathrm{H}, \mathrm{Ph}), 5.44$ (d, $1 \mathrm{H}, \mathrm{H}-3), 4.50$ (dd, $1 \mathrm{H}, \mathrm{H}-4), 4.41$ (dd, $1 \mathrm{H}$, H-6a), 4.33 (dd, 1 H, H-5), 4.11 (d, 1 H, H-6b), 4.10 (d, 1 H, H-1a), 4.05 (d, $1 \mathrm{H}, \mathrm{H}-1 \mathrm{~b}), 2.05$ (s, $3 \mathrm{H}, \mathrm{NMe}), 1.62,1.36(2 \mathrm{~s}$, each $3 \mathrm{H}$, $\mathrm{CMe}_{2}$ ) ppm. ${ }^{13} \mathrm{C}$ NMR $\left(125.7 \mathrm{MHz}, \mathrm{CDCl}_{3}\right): \delta=169.5(\mathrm{CO}), 166.0$ $(\mathrm{CN}), 138.1,129.8,129.4,128.4(\mathrm{Ph}), 109.5\left(\mathrm{CMe}_{2}\right), 100.7(\mathrm{C}-2)$, 75.2 (C-4), 74.2 (C-1), 74.1 (C-5), 72.9 (C-3) 61.1 (C-6), 27.8, 26.4 $\left(2 \mathrm{CMe}_{2}\right), 14.3$ (NMe) ppm.

Selected data 22 for 9: $\mathrm{R}_{\mathrm{f}}=0.25$ (1:2 EtOAc-petroleum ether); $[\alpha]_{\mathrm{D}}$ $+68\left(c 1.0, \mathrm{CH}_{2} \mathrm{Cl}_{2}\right) .{ }^{1} \mathrm{H}$ NMR $\left(500 \mathrm{MHz}, \mathrm{CDCl}_{3}\right): \delta=7.37-7.24(\mathrm{~m}$, $15 \mathrm{H}, 3 \mathrm{Ph}), 4.67\left(\mathrm{~d}, 1 \mathrm{H}, \mathrm{CH}_{2} \mathrm{Ph}\right), 4.62\left(\mathrm{~d}, 1 \mathrm{H}, \mathrm{CH}_{2} \mathrm{Ph}\right), 4.54$ (br s, $2 \mathrm{H}, \mathrm{H}-1), 4.52\left(\mathrm{~d}, 1 \mathrm{H}, \mathrm{CH}_{2} \mathrm{Ph}\right), 4.48\left(\mathrm{~d}, 1 \mathrm{H}, \mathrm{CH}_{2} \mathrm{Ph}\right), 4.41(\mathrm{~d}, 1 \mathrm{H}$, $\left.\mathrm{CH}_{2} \mathrm{Ph}\right), 4.32$ (dt, $\left.1 \mathrm{H}, \mathrm{H}-5\right), 4.17\left(\mathrm{~d}, 1 \mathrm{H}, \mathrm{CH}_{2} \mathrm{Ph}\right), 4.16(\mathrm{~d}, 1 \mathrm{H}, \mathrm{H}-$ 3), 4.02 (dd, $1 \mathrm{H}, \mathrm{H}-4), 3.58$ (dd, $1 \mathrm{H}, \mathrm{H}-6 \mathrm{a}), 3.53$ (dd, $1 \mathrm{H}, \mathrm{H}-6 \mathrm{~b}$ ), $2.06(\mathrm{~s}, 3 \mathrm{H}, \mathrm{NMe}) \mathrm{ppm} .{ }^{13} \mathrm{C} \mathrm{NMR}\left(125.7 \mathrm{MHz}, \mathrm{CDCl}_{3}\right): \delta=168.5$ $(\mathrm{CN}), 138.0,137.9,137.4,127.6,126.9(\mathrm{Ph}), 107.8(\mathrm{C}-2), 87.9(\mathrm{C}-$ 3), 81.8 (C-4), 80.2 (C-5), $73.3(\mathrm{C}-1), 72.4,72.1,72.0,\left(\mathrm{CH}_{2} \mathrm{Ph}\right)$, 69.7 (C-6), 14.5 (NMe) ppm.

Selected data ${ }^{22}$ for 10: $\mathrm{R}_{\mathrm{f}}=0.53$ (1:4 EtOAc-petroleum ether); $[\alpha]_{\mathrm{D}}$ $-42\left(c 1.1, \mathrm{CH}_{2} \mathrm{Cl}_{2}\right) .{ }^{1} \mathrm{H} \mathrm{NMR}\left(500 \mathrm{MHz}, \mathrm{CDCl}_{3}\right): \delta=8.08-7.24(\mathrm{~m}$, $15 \mathrm{H}, \mathrm{Ph}), 6.03$ (t, $1 \mathrm{H}, \mathrm{H}-4), 4.81(\mathrm{~d}, 1 \mathrm{H}, \mathrm{H}-3), 4.81(\mathrm{dd}, 1 \mathrm{H}, \mathrm{H}-$ 6a), 4.71 (dd, 1 H, H-6b), 4.56 (m, 1 H, H-5), 4.51 (d, $1 \mathrm{H}, \mathrm{H}-1 \mathrm{a})$, 4.33 (d, $1 \mathrm{H}, \mathrm{H}-1 \mathrm{~b}), 1.98$ (s, $3 \mathrm{H}, \mathrm{NMe}) \mathrm{ppm} .{ }^{13} \mathrm{C} \mathrm{NMR}(125.7 \mathrm{MHz}$, $\left.\mathrm{CDCl}_{3}\right): \delta=169.5(\mathrm{CN}), 166.3,166.0,165.6(\mathrm{CO})$ 133.7, 133.6, 130.1, 129.9, 128.5, $128.3(\mathrm{Ph}), 106.5(\mathrm{C}-2), 78.8(\mathrm{C}-5), 78.6(\mathrm{C}-3)$, 77.1 (C-4), 73.5 (C-1), 65.9 (C-6), 14.4 (NMe) ppm.

Selected data ${ }^{22}$ for 11: $\mathrm{R}_{\mathrm{f}}=0.29$ (1:4 EtOAc-petroleum ether); $[\alpha]_{\mathrm{D}}$ $-28\left(c 5.8, \mathrm{CH}_{2} \mathrm{Cl}_{2}\right) .{ }^{1} \mathrm{H}$ NMR $\left(500 \mathrm{MHz}, \mathrm{CDCl}_{3}\right): \delta=8.07-7.24(\mathrm{~m}$, $15 \mathrm{H}, \mathrm{Ph}), 5.70(\mathrm{~d}, 1 \mathrm{H}, \mathrm{H}-3), 5.61(\mathrm{dd}, 1 \mathrm{H}, \mathrm{H}-4), 4.79(\mathrm{dd}, 1 \mathrm{H}, \mathrm{H}-$ 6a), 4.70 (ddd, 1 H, H-5), 4.65 (dd, 1 H, H-6b), 4.32 (s, 2 H, H-1), 2.09 (s, $3 \mathrm{H}, \mathrm{NMe}) \mathrm{ppm} .{ }^{13} \mathrm{C} \mathrm{NMR}\left(125.7 \mathrm{MHz}, \mathrm{CDCl}_{3}\right): \delta=169.2$ $(\mathrm{CN}), 133.8,133.5,133.3,129.9,129.7,129.2,128.8,128.3(\mathrm{Ph})$, 108.7 (C-2), 82.3 (C-4), 79.8 (C-5), 79.1 (C-3), 71.5 (C-1), 63.8 (C6), $14.5(\mathrm{NMe}) \mathrm{ppm}$.

\section{Acknowledgment}

We thank the Spanish Ministerio de Ciencia y Tecnología for financial support (contracts number BQU2003-00937 and BCM20012366-CO3-03). E. M. R. thanks the CSIC for a fellowship.

\section{References}

(1) For a review, see: Grant, T. G.; Meyer, A. I. Tetrahedron 1994, 50, 2297.

(2) For reviews, see: (a) Jönsson, C.; Hallman, K.; Andersson, H.; Stemme, G.; Malkoch, M.; Malmströn, E.; Hult, A.; Moberg, C. Bioorg. Med. Chem. Lett. 2002, 12, 1857. (b) Ghosh, A. K.; Mathivanan, P.; Cappiello, J. Tetrahedron: Asymmetry 1998, 9, 1 .
(3) For recent publications, see: (a) Jones, G.; Richards, C. J. Tetrahedron: Asymmetry 2004, 15, 653. (b) Aït-Haddou, H.; Hoarau, O.; Cramailére, D.; Pezet, F.; Daran, J.-C.; Balavoine, G. G. A. Chem.-Eur. J. 2004, 10, 699.

(4) (a) Mitchel, J. P.; Patteden, A. G. Angew. Chem., Int. Ed. Engl. 1993, 32, 1. (b) Vorbrüggen, H.; Krolikiewicz, K. Tetrahedron 1993, 49, 9353.

(5) (a) Wittmann, V.; Lennartz, D. Eur. J. Org. Chem. 2002, 1363. (b) Banoub, J. Chem. Rev. 1992, 92, 1167. (c) Stöckl, W. P.; Weidmann, H. J. Carbohydr. Chem. 1989, 8, 169.

(6) Colon, M.; Staveski, M. M.; Davis, J. T. Tetrahedron Lett. 1991, 32, 4447.

(7) Knapp, S.; Yang, C.; Haimowitz, T. Tetrahedron Lett. 2002, 43, 7101

(8) Damkaci, F.; DeShong, P. J. Am. Chem. Soc. 2003, 125, 4408.

(9) Johnson, F.; Madronero, R. Adv. Heterocycl. Chem. 1996, 6, 95.

(10) (a) Yu, M.; Pagenkopf, B. L. J. Am. Chem. Soc. 2003, 125, 8122. (b) Lohse, A.; Schweizer, F.; Hindsgaul, O. Comb. Chem. High Throughput Screening 2002, 5, 389.

(c) Schweizer, F.; Lohse, A.; Otter, A.; Hindsgaul, O. Synlett 2001, 1434. (d) Nair, L. G.; Fraser-Reid, B.; Szardenings, A. K. Org. Lett. 2001, 3, 317. (e) Ratcliffe, A. J.; Konradsson, P.; Fraser-Reid, B. J. Am. Chem. Soc. 1990, 112, 5665.

(11) Pavia, A. A.; Ung-Chhun, S. A.; Durand, J.-L. J. Org. Chem. 1981, 46, 3158 .

(12) (a) Noort, D.; van der Marel, G. A.; Mulder, G. J.; van Boom, J. H. Synlett 1992, 224. (b) Gordon, D. M.; Danishefsky, S. J. J. Org. Chem. 1991, 56, 3713.

(13) Rubio, E. M.; Ortiz Mellet, C.; García Fernández, J. M. Org. Lett. 2003, 873.

(14) Brady, R. F. Jr. Adv. Carbohydr. Chem. 1971, 26, 197.

(15) Holerca, M. N.; Percec, V. Eur. J. Org. Chem. 2000, 2257.

(16) Aoi, K.; Okada, M. Prog. Polym. Sci. 1996, 21, 151.

(17) Compound 7a had previously been obtained by reaction of 2 with trimethylsilyl triflate. See: Gash, C.; Pradera, M. A.; Salameh, B. A. B.; Molina, J. L.; Fuentes, J. Tetrahedron: Asymmetry 2001, 12, 1267.

(18) Tvaroska, I.; Bleha, T. Adv. Carbohydr. Chem. Biochem. 1989, 47, 45

(19) Ratcliffe, A. J.; Fraser-Reid, B. J. Chem. Soc., Perkin Trans. 1 1989, 112, 147.

(20) (a) Timmers, C. M.; Turner, J. J.; Ward, C. M.; van der Marel, G. A.; Kouwijzer, M. L. C. E.; Grootenhuis, P. D. J.; van Boom, J. H. Chem.-Eur. J. 1997, 3, 920. (b) Benito, J. M.; Ortiz Mellet, C.; Sadalapure, K.; Lindhorst, T. K.; Defaye, J.; García Fernández, J. M. Carbohydr. Res. 1999, $320,37$.

(21) Benito, J. M.; Gómez-García, M.; Ortiz Mellet, C.; García Fernández, J. M.; Defaye, J. Org. Lett. 2001, 3, 549.

(22) The notation of atoms for NMR data has been kept consistent with that of the parent D-fructose precursor. 